\title{
Non-financial key performance indicators: what determines the differences in the quality and quantity of the disclosures?
}

\author{
Ewelina Zarzycka \\ University of Lodz, Lodz, Poland, and \\ Joanna Krasodomska \\ Cracow University of Economics, Krakow, Poland
}

Non-financial key

performance indicators

\begin{abstract}
Purpose - The paper aims to examine if corporate characteristics, general contextual factors and the internal context differentiate the quality and quantity of the disclosed non-financial Key Performance Indicators (KPIs). Design/methodology/approach - The study is based on content analysis of the disclosures provided by large public interest entities operating in Poland after the introduction of the Directive 2014/95/EU. The quality of the KPIs disclosures is measured with the disclosure index. Regression analysis and selected statistical tests are used to examine the influence of the selected factors on the differences in the index value and corporate disclosure choices as regards the KPIs.

Findings - The study findings indicate that the sample companies provide a variety of non-financial KPIs in a manner that makes their effective comparison difficult. The research confirms that mainly industry, ecologists and the reporting standard determine the significant differences in the quality of the KPIs disclosures and the quantity of presented KPIs.

Research limitations/implications - The paper adds to the understanding of the differences in the quality of KPIs presentation and the choice of disclosed KPIs.

Practical implications - The paper includes suggestions on how to change corporate practice with regard to the non-financial KPIs disclosures.

Originality/value - We shed additional light on the importance of internal contextual factors such as the reporting standard and the reporters' experience in providing non-financial KPIs disclosures.
\end{abstract}

Keywords KPIs, Directive 2014/95/EU, Non-financial reporting, Sustainability, Stakeholders

Paper type Research paper

\section{Introduction}

The Directive 2014/95/EU (EU, 2014) was introduced in the European Union (EU) to increase "the relevance, consistency, and comparability of information disclosed by certain large undertakings and groups across the Union" (EU, 2014, Introduction par. 21; Venturelli et al., 2020) in response to external pressures, mostly from investors, a network of non-governmental organizations and trade unions (Monciardini, 2016). It seems that by choosing the significantly cheaper minimum harmonization approach, not supported by

(C) Ewelina Zarzycka and Joanna Krasodomska. Published by Emerald Publishing Limited. This article is published under the Creative Commons Attribution (CC BY 4.0) licence. Anyone may reproduce, distribute, translate and create derivative works of this article (for both commercial and non-commercial purposes), subject to full attribution to the original publication and authors. The full terms of this licence may be seen at http://creativecommons.org/licences/by/4.0/legalcode

The authors wish to thank the participants of the 9th International Conference Financial Reporting and Auditing: Meeting the information users' needs, held in Krakow, Poland, in December 2019 for their helpful feedback, comments and suggestions. This work was supported by the National Science Centre, Poland under Grant number 2019/33/B/HS4/00998.

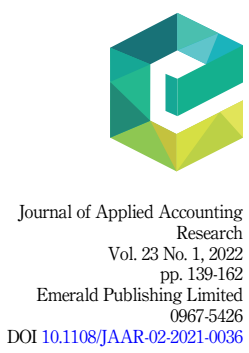


JAAR

23,1

detailed rules and standards for the collection and processing of the information, the Directive, in the end, did not produce significant effects (e.g. EC, 2020; Szabó and Sørensen, 2015; Doni et al., 2019; Di Tullio et al., 2019; Nicolo et al., 2020; Pizzi et al., 2020; Venturelli et al., 2020).

According to the progress report of the Project Task Force on preparatory work for the elaboration of possible EU non-financial reporting standards (PTF-NFRS), close to 100 relevant frameworks have been identified in relation to non-financial disclosures (EFRAG, 2020), and they can be used separately or simultaneously. Additional industry-based standards can be implemented as well. Apart from international standards, regional and national regulations or guidelines can be used. Companies can also follow their own reporting strategies. Non-financial information can be presented within the corporate annual report, as a separate report, on the corporate website or social media. It might be offered as narratives or as indicators.

What is more, given the nature of non-financial information, while preparing the disclosures, it is necessary to take into consideration not only regulations and guidelines but also stakeholder information needs which should be determined using corporate dialogue. Companies' operations and performance are currently under constant scrutiny by investors, employees, consumers, regulators and other stakeholders (Hussainey and Salama, 2010; Lehner and Harrer, 2019). Many of them care about firms' contributions to sustainable development (Mio et al., 2020) and demand such disclosures (De Villiers, 2018). Therefore, non-financial disclosure has become an expected component of corporate stakeholder relations. Given the above, non-financial disclosures, despite being regulated and enforced to some extent, still depend on the companies' own decisions. Such decisions, in turn, are driven by various factors which relate to (1) corporate characteristics, (2) general contextual factors and (3) the internal context (Adams, 2002).

As Korca and Costa (2021) argue, to date there is a lack of research on the interaction between contextual factors and the Directive 2014/95/EU. The current paper attempts to answer this call by focusing on the corporate non-financial disclosures provided as Key Performance Indicators (KPIs). It aims to examine if the selected factors representing organizational characteristics (namely industry), general contextual factors (more specifically stakeholders' influence) as well as the internal context (such as experience in voluntary non-financial disclosures and the decision to use a particular reporting standard) differentiate the quality of KPIs disclosure and the quantity of the KPIs disclosed. In this study we focus on the disclosures of KPIs provided by the large public interest entities (PIEs) operating in Poland in their non-financial statements published in 2019. We analyze the handcollected data using content analysis and binary disclosure index. The research hypotheses regarding the impact of the above-mentioned factors on the KPIs disclosures are tested with the use of regression analysis and statistical tests.

Our paper contributes to the sustainability accounting literature in several ways. First, we explore a relatively new setting by providing new information on the sustainability disclosures in a country that is neither West European, nor Australasian, nor the USA. According to Tilt (2016), the drawback of some of the studies being carried out is that they fail to investigate thoroughly the contextual factors that influence the development of the sustainability concept and related reporting in those countries, giving preference to reliance on theories and hypotheses developed from studies undertaken in the West. In our study, we focus on the Polish setting, which is, as we believe, interesting and relatively unexplored. For example, in the recent Accountancy Europe report, Poland is an unknown gray field on the EU map presenting an overview of the transposition of the Directive 2014/95/EU as regards the statutory audit of non-financial disclosure (Accountancy Europe, 2020). Therefore, we hope to fill these blank spots by adding some further information on the Directive implementation and regulatory framework regarding sustainability reporting in Poland, with 
a particular focus on KPIs disclosures. Second, we focus only on KPIs disclosures. Most of the previous studies aimed at investigating narrative disclosures or narratives and KPIs mixed with the use of disclosure index (e.g. Lim et al., 2007; Beck et al., 2010; Michelon et al., 2015; Dumitru et al., 2017; Venturelli et al., 2017; Venturelli et al., 2019a) and only a few explicitly focused on KPIs disclosures (e.g. Beyne and Wee, 2019; Loprevite et al., 2020; Krasodomska and Zarzycka, 2020). Third, the scarce studies that focused on KPIs disclosures were aimed at research problems concerning KPIs, but not necessarily at investigating the factors that influence the corporate disclosure decisions. Fourth, we add to our analysis two unexploited factors related to the internal context-experience in voluntary non-financial disclosures and the decision to use a specific reporting standard. Fifth, we measure the quality of KPIs disclosure, which, to the best of our knowledge, has not been investigated before with the use of the disclosure index.

The practical implication of our study stems from the arguments supporting the conviction that it is time to abandon the approach whereby a wide variety of KPIs is presented at management's discretion irrespective of their relevance for the corporate strategy or stakeholders and with no consideration for the guidelines that suggest how they should be disclosed. As a result of the current practice, the corporate non-financial disclosures (including KPIs) are of large volume and poor quality (Michelon et al., 2015). EU-based companies' managers need to reconsider their approach to KPIs use and disclosure also due to the forthcoming changes introduced by the EU's Sustainable Finance Disclosure and Taxonomy Regulations (EU, 2019, 2020b). If large PIEs do not start changing their ways of reporting now, they may not be able to comply with the first set of new requirements in 2022, when they will need to provide (most of them for the first time) three KPIs, namely the proportion of their turnover, their capital expenditure ("CapEx") and their operating expenditure ("OpEx") related to environmentally sustainable activities (EU, 2020b). What is more, KPIs are also an important element of the new architecture of the EU sustainability reporting standard-setting proposed by European Lab PTF-NFRS in March 2021 (EFRAG, 2021).

The remainder of this paper unfolds as follows. The ensuing section presents the nonfinancial reporting guidelines which refer to KPIs disclosures. Next, the theoretical background is provided, followed by the literature review and hypotheses development. After that the method employed for empirical research is explained. The paper then proceeds to present the results of the study. The paper concludes by summarizing the overall contribution of this paper, addressing the limitations of the work and suggesting recommendations for future research.

\section{Institutional background}

European Commission (EC) defines KPIs as indicator-based disclosures, which are "consistent with metrics actually used by the company in its internal management and risk assessment process" (EC, 2017, p. 13). They should be broadly recognized, material, useful, relevant and of high quality. KPIs should improve transparency and comparability of corporate disclosures. Accompanying narratives help to understand KPIs, especially when they are industry-related since their presentation might involve using a specific terminology that might not be easily understood by stakeholders. Therefore, the provision of narrative commentary explaining how they are measured and used for internal purposes helps to make the non-financial statement more understandable and useful (EC, 2017).

The number of KPIs included in the non-financial statement is also relevant. The EC guidelines (EC, 2017) do not prescribe the optimal number of KPIs. However, in order for KPIs to be useful, their number should be limited to the truly important, in other words, the "key" ones. Presentation of a large variety of KPIs without indicating which of them are crucial for assessing corporate performance does not enhance transparency or comparability of the
Non-financial key performance indicators 
JAAR 23,1

disclosure. According to the literature, the optimum number of KPIs is quite limited. As Parmenter (2015, p. 21) argues, "many organizations will operate very successfully with no more than ten of them, and it is a myth that the more KPIs there are, the better performance measurement will be. In fact, as has no doubt been witnessed by many readers, the reverse is true".

As EC guidelines indicate, corporate stakeholders value the information which helps them measure progress, check consistency over time and draw comparisons (EC, 2017). Therefore, KPIs are particularly useful. They should be consistently used with time, and their past, current and projected values should be presented. This approach would allow evaluating progress and trends, explaining why KPIs increased or decreased in the reporting year, and how they might evolve in the future. Companies may present KPIs in the context of targets and past performance and provide a comparison with other companies, as appropriate. Since companies may rely on various non-financial reporting frameworks to present KPIs, they should explain how the data was collected and how the indicators were calculated, as well as the frameworks relied upon.

It should be noted that the first set of guidelines referred to above, published by the EC in 2017 does not recommend any specific KPIs. The second set of guidelines, which focuses on climate change and was published by the EC in 2019, is far more precise in this regard (EC, 2019). It presents 14 KPIs in categories such as GHG emissions, energy, physical risk, products and services, green finance, along with the unit of measure, an example, rationale, alignment with other reporting frameworks, and the EU policy reference. The guidelines also indicate that it is considered good practice to publish an additional table that presents all indicators in one place.

When preparing the guidelines, the EC reviewed available national, EU-based and international non-financial reporting frameworks. Several propose their approach to the KPIs disclosure (e.g. UN Global Compact, 2020; SASB, 2013; UNCTAD, 2019; GRI, 2021a; EFFAS_DVFA, 2010; EU, 2020a). In addition to the ones mentioned above, other international frameworks also include practical guidance on KPIs' qualitative characteristics and how to disclose them (e.g. IIRC, 2013; CDSB, 2018).

In our study, we focus on the Polish setting. Poland was one of the countries that opposed implementation of the Directive 2014/95/EU. The Polish government favored recommendations or guidelines as they were considered a better approach to increasing the scope and quality of non-financial disclosures than an introduction of changes in the accounting law (Szewc and Abec, 2015). The Directive was implemented at the minimum level by incorporating its requirements into the Act on Accounting in December 2016 (Accounting Act, 2016). It should be noted that despite this somewhat cold reception of the changes in the reporting regulations, the number of companies in Poland that voluntarily provided nonfinancial disclosures according to GRI before the Directive 2014/95/EU came into force was higher than in other countries of the former Eastern European Bloc (GRI, 2021b).

Apart from the Accounting Act, which includes the main Directive requirements in par. 49, further guidance on how to disclose non-financial information, also KPIs, is included in Polish Krajowy Standard Rachunkowości (National Accounting Standard-NAS) No. 9, issued in 2014 by the Polish Accounting Standards Committee and updated after the implementation of the EU Directive in January 2018 (NAS 9, 2018). The purpose of the standard is to assist companies in the preparation of the management commentary, which will meet the users' expectations and promote the best practices. As regards the disclosure of KPIs, the NAS 9 stresses the need to present the purpose of their use, how they were calculated and the data source. KPIs should be presented at least for the current and previous periods, but it is a good practice to include more extended timeframes like 3 or 5 years. Any changes in the KPIs' values should be interpreted, and the reasons for them should be explained. It is useful to indicate any trends and future values of KPIs, as well as to compare 
them with the benchmark values or mean values for the industry. It is especially useful to confront the KPIs values with the target (future) values or values considered as desired (e.g. indicated by the guidelines) and their past values. The disclosures provided by the reporting entity should allow the KPIs to be compared with other companies and should be as useful as possible to measure, monitor and evaluate the entity's development, performance and impacts. It should be noted that NAS 9 is not widely referred to in the corporate practice or in the debates around non-financial reporting in Poland.

Another standard, which in contrast to NAS 9 originated from the private body and is widely used in corporate practice, is the Standard Informacji Niefinansowych (Nonfinancial Information Standard - NFIS), published in October 2017 in response to the obligations introduced by the Directive 2014/95/EU (NFIS, 2017). Its development was supervised by the Foundation for Reporting Standards (FRS) and the Association of Stock Exchange Issuers. In related consultations, there also participated other organizations and institutions and experts with experience in non-financial information reporting, sustainable development and responsible business. At the beginning of 2018, the FSR published an example of the nonfinancial report structure prepared according to NFIS to provide further guidance for companies. NFIS consists of the main part and five annexes. The main part comprises guidelines for reporters and $123 \mathrm{KPIs}$ grouped in three areas: managerial issues (15 KPIs), environment protection (30 KPIs) and social and employee matters (78 KPIs). Five annexes are integral parts of the standard. Four of them relate to the following topics: additional information on the reporting areas, further information on the Directive and Accounting Act, stakeholders, KPIs. The last annex includes the materiality matrix that provides guidance on which indicators proposed by the NFIS are material for the companies operating in a particular industry. There are four options available: high materiality, medium materiality, low materiality and not applicable.

Despite the additional guidance provided by both standards, the first reporting year after the Directive came into force revealed that the least disclosures complying with the Accounting Act requirements and the most significant number of deficiencies in the large PIE's reports concerned KPIs. (Fijałkowska et al., 2019, p. 141). According to the Polish Ministry of Finance Report, analyzing the corporate reports prepared for the first time under the new requirements, "a problem has been observed as regards the obligation to present nonfinancial KPIs. This obligation is intended to make the entity/group disclose these nonfinancial indicators which are essential for the entity, i.e., taken into account in its strategic and operational decisions, in the same way as key financial performance indicators. After careful examination, it turned out that this obligation was correctly met in less than half of the cases" (Ministry of Finance, 2019, p. 121).

\section{Theoretical underpinning}

In the last 30 years, a growing number of researchers have used stakeholder theory to demonstrate the complexity and challenges that companies encounter when providing nonfinancial disclosures (Rimmel and Jonäll, 2020). According to this theory, a key characteristic of effective organizational management is determined by the group of interdependent relationships that exist between the company and its key stakeholders (Idowu et al., 2013). A stakeholder is an individual or a group who is influenced by decisions made by the organization or who themselves can influence the organization's decisions (Freeman, 1984). These decisions also include companies' information policies. According to Miles (2019), stakeholder theory was first proposed by Ullmann (1985) as a framework for explaining voluntary disclosure. The underlying logic was that stakeholders request sustainability information, and those with more power to influence the company are more likely to have their needs satisfied.
Non-financial key performance indicators 
JAAR 23,1

144

It is commonly accepted that some stakeholder groups can be more influential than others. Investors are considered a primary stakeholder, as they are a crucial component to any company, which without them, would not be able to operate (Mishra and Suar, 2010). In the sustainability context, socially responsible investors are particularly important. They are assumed to have interests in the companies' social and environment-related initiatives, which positively influence their long-term value, and at the same time, their investment return (Salehi et al., 2019). Usually, primary stakeholders also include employees, who are especially important for every organization, as they create human capital, which is central to competitive advantage (Mishra and Suar, 2010; Haski-Leventhal, 2013). In relation to customers, the evidence shows that increased salience of customers as a stakeholder group influences managers' sustainability-related decisions. Customers expect firms to be highly responsible in terms of products and services they offer (Mishra and Suar, 2010). Environmental and social activities and related disclosures are also crucial in developing positive brand attitudes and thus influencing the customers' and other stakeholders' decisions (Banerjee et al., 2003). A company's environmental responsiveness helps it minimize environmental risks, lower operating costs and consequently increase its revenue (Idowu et al., 2013). Local communities, and particularly ecological activists or lobby groups, are seen as important stakeholders (Banerjee et al., 2003; Gamerschlag et al., 2011).

It should be noted that stakeholders' non-financial information needs and the industry in which a company operates are closely related (Fernandez-Feijoo et al., 2014). Since the companies in particular industries make attempts to meet the specific information needs of their stakeholders, the industry was found to be an important determinant of corporate information policy in many studies (e.g. Fifka, 2013; Gamerschlag et al., 2011; Ho and Taylor, 2007; Salehi et al., 2019; Al Farooque and Ahulu, 2017). For example, companies operating in the environment-sensitive industry receive more attention from environment-focused stakeholders. Such stakeholders can have the power to influence politicians and the general public to impose costs on companies with bad environmental performance. Consequently, these companies have more incentives to disclose non-financial information, especially environment-related, to reduce these costs (Deegan and Gordon 1996; Gamerschlag et al., 2011).

As Lisi (2018) argues, companies strive to improve their alignment with the growing concerns and expectations of their stakeholders by providing non-financial disclosures. In order to achieve this alignment, stakeholder engagement is needed. The company's engagement with stakeholders can even be regarded as the essence of Corporate Social Responsibility (CSR) (Pedersen, 2006). According to Kaur and Lodhia (2018), the interaction between companies and their stakeholders has become more proactive over the years, and the approach "inform me" has been replaced by "engage me." Stakeholder engagement emphasizes active participation and knowledge sharing and can take different forms, including dialogue. While conducting successful dialogue with their stakeholders, companies interact with them, exchange views and opinions, influence each other and learn from each other. As an effect of the interactive mutual learning processes, transformative actions and changes desirable for both sides are introduced (Belucci and Manetti, 2017). These changes also relate to the company's disclosure strategy regarding non-financial issues, as stakeholder engagement is crucial for the entire sustainability accounting and reporting process (Kaur and Lodhia, 2018). The CSR (or non-financial) reporting itself can be understood as a part of the dialogue between the company and its stakeholders (PradoLorenzo et al., 2009). The need to engage stakeholders, also by means of the dialogue, is stressed, e.g. in GRI Standards (GRI, 2021a) and NFIS (2017), mentioned above. It is worth adding that both standards emphasize that all companies' stakeholder groups need to be equally considered [1]. In accordance with GRI Disclosure 102-43, the company should report on its approach to stakeholder engagement, including frequency of engagement by type and 
by stakeholder group and an indication of whether any of the engagement was undertaken specifically as part of the report preparation process (GRI, 2021a).

\section{Literature review and hypotheses development}

The performed literature review allowed us to conclude that there are not many studies which focus specifically on the factors influencing the disclosure of non-financial KPIs and its quality. Non-financial KPIs were found to be used in corporate reporting (Arvidsson, 2011), and what is more, to directly affect the company's social performance and indirectly its bottom line (Lisi, 2018). Similarly, Loprevite et al. (2020) identified a positive association between the level of disclosure on KPIs and financial performance. Bradley and Botchway (2018) focused on the use of KPIs in the coffee industry and found a considerable variance in the KPIs disclosed, which led them to the conclusion about the discretionary nature of nonfinancial reporting.

We believe that particular attention needs to be paid to the extensiveness of KPIs reporting, the quality and quantity of the information provided, and critical analysis of the (potential) role of mandatory regulation in achieving improvements in the above areas. Therefore, we focus on the factors that influence the corporate reporting decisions. These factors can be divided into three categories: (1) corporate characteristics, (2) general contextual factors and (3) the internal context (Adams, 2002).

Corporate characteristics that influence non-financial reporting decisions include factors such as industry group, size, financial/economic performance, trade sharing volume, price and risk (Adams, 2002). In our study, we focus on the industry as an important determinant. There is a general agreement in the non-financial accounting literature that sustainability disclosure is related to the industry in which the reporting company operates. Sector-level differences are even considered as the primary internal determinant of non-financial reporting (Fifka, 2013). The influence of various industry types on the volume of non-financial disclosures provided was identified by Gamerschlag et al. (2011), Ho and Taylor (2007), Salehi et al. (2019). Al Farooque and Ahulu (2017) study confirms that industry sector is the dominant determinant of social and economic reporting and higher levels of disclosure are linked to sensitive industry sectors. More precisely, environmentally sensitive industries such as mining, energy, forestry, chemicals, construction materials and steel provide more non-financial disclosures (Lock and Seele, 2016; Branco and Rodrigues, 2008; Jenkins and Yakovleva, 2006; Fifka and Drabble, 2012). Basing on the conducted literature review, we formulate the following hypotheses:

H1a. The industry in which the company operates determines the differences in the quality of the corporate non-financial KPIs disclosures.

H1b. The industry in which the company operates determines the differences in the quantity of the non-financial KPIs disclosed by the companies.

We believe that stakeholder groups' pressure is another important contextual factor that influences non-financial disclosures. Fernandez-Feijoo et al. (2014) argue that the pressure of some groups of stakeholders (customers, clients, employees and environment) improves the transparency of the corporate disclosure. The obligation to consider stakeholder information needs is stressed by the EC guidelines and reporting frameworks and in the literature (e.g. Crane and Livesey, 2003; Kaur and Lodhia, 2018; Belluci and Manetti, 2017; Venturelli et al., 2020; Krasodomska and Zarzycka, 2020). Thus, companies need to become more proactive and transparent in non-financial reporting (Rodrigue et al., 2013). Especially socially responsible investors (Rinaldi et al., 2014; Eurosif, 2016), community stakeholders such as ecological activists (Banerjee et al., 2003; Gamerschlag et al., 2011), customers (Banerjee et al.,
Non-financial key performance indicators 
JAAR

23,1

146

2003; Mishra and Suar, 2010) and employees (Haski-Leventhal, 2013) are in the center of sustainability-related initiatives and non-financial reporting strategies. Based on this theoretical consideration and state of the art in the literature, we developed the following hypotheses:

H2a. The company's stakeholder pressure determines the differences in the quality of the corporate non-financial KPIs disclosures.

H2b. The company's stakeholder pressure determines the differences in the quantity of the non-financial KPIs disclosed by the companies.

We add two more factors, which are related to the company's internal decisions and, we believe, might explain non-financial reporting decisions: the reporting standard used and previous experience in sustainability reporting. The corporate management decision to choose one reporting framework over another can have a direct impact on the quality and scope of the disclosures provided. As Akisik and Gal (2011) state, there is evidence that sustainable development is strongly related to sustainability reporting and accounting standards, even after controlling for a variety of macroeconomic factors. GRI standards can be referred to as the de facto global CSR disclosure framework (De Villiers and Marques, 2016). They are used most widely and considered to be the best option available for companies to use in non-financial reporting, as well as the "backbone of most voluntary and mandatory regulatory attempts at reporting on CSR issues" (Lock and Seele, 2016, p. 3). They are regarded as a factor positively influencing the credibility of the disclosure. According to Hoffmann et al. (2018), reports based on GRI or local standards are also more likely to be in line with the requirements of the Directive 2014/95/EU. Therefore, we posit that:

$H 3 a$. The company's non-financial reporting standard determines the differences in the quality of the corporate non-financial KPIs disclosures.

$H 3 b$. The company's non-financial reporting standard determines the differences in the quantity of the non-financial KPIs disclosed by the companies.

Before the introduction of the Directive 2014/95/EU, many companies practiced non-financial reporting voluntarily. The more experience the company has in the business, and the longer it has reported on non-financial issues, the more practice it has acquired (Lock and Seele, 2016). The experience gained by the companies which have been practicing such reporting before should result in a higher quality of voluntarily provided disclosures (Ruhnke and Gabriel, 2013). Albertini (2013) research results show that non-financial disclosure becomes increasingly technical and precise with time. The challenges posed by the new reporting requirements are not so difficult for the companies which have been practicing sustainability reporting before as they already have appropriate working policies in place. As for other companies, the need to follow the new accounting law might require significant organizational changes due to the necessity to collect brand new non-financial data (cf. Cormier et al., 2005). Accordingly, we develop the following hypotheses:

H4a. The company's experience in non-financial reporting determines the differences in the quality of the corporate non-financial KPIs disclosures.

$H 4 b$. The company's experience in non-financial reporting determines the differences in the quantity of the non-financial KPIs disclosed by the companies.

Thus, the aim of our study is to examine if the selected factors representing corporate characteristics, general contextual factors as well as the internal context impact the KPIs disclosures in companies, mainly as regards the quality of the disclosures and the quantity of the disclosed KPIs. Previous research findings (Krasodomska, 2013; Waniak-Michalak, 2017; 
Szadziewska et al., 2018; Skoczylas, 2019), as well as the Polish Ministry of Finance (2019), allowed us to expect that the sample companies would present KPIs differently.

\section{Research design}

The sample consists of 169 large PIEs operating in Poland and required to provide nonfinancial disclosures according to the new accounting law. It covers all entities which fell under the Directive's scope in Poland. The sample companies are the most advanced entities in Poland regarding the implementation of the CSR concept and the source of non-financial reporting good practices. Non-financial statements of the sample companies published in 2019 were downloaded from the website https://standardy.org.pl/raporty-spolek (FSR, 2020) in the PDF format and the database with reports was created. Subsequently content analysis of the disclosures was performed.

Content analysis is widely used in disclosure studies as a legitimate method of collecting data (Beattie and Thomson, 2007; Guthrie, 2014). In the first step of the empirical research, content analysis of the downloaded corporate reports was performed. Coding consisted of transferring the information on KPIs included in a non-financial statement to an observation sheet created in an Excel file. The coding procedure was performed by the co-authors from September 2019 to February 2020. The intercoder reliability was tested with the use of Krippendorf's alpha (b) (Lombard et al., 2002).

The focus of the investigation was on disclosures on non-financial KPIs. In this study, we use the most reliable form of content analysis as indicated by Abdolmohammadi (2005), as we search the text for specific terms, such as "KPI", "indicator" "non-financial indicator". Therefore, since we do not focus on coding sentences and paragraphs, we do not have to make subjective judgments about the meaning or importance of the subject matter.

During content analysis of the reports, attention was given not only to the type and number of non-financial KPIs disclosed but also to how they are presented. While coding, KPIs were divided into the following main areas: environmental matters, societal matters, employee matters, in consonance with She and Michelon (2019) and Okazaki et al. (2020). The simple binary $(0,1)$ coding scheme was used in order to state the presence or absence of an item in each category. The list of KPIs evolved during content analysis. More specifically, KPIs were determined in the pilot study based on 10 randomly selected companies. Still, in the course of the research, when a new KPI was identified in a subsequent company's nonfinancial statement, it was added to the list in the observation sheet.

As indicated above, while performing content analysis, we also capture the KPIs disclosures' quality. For that purpose, we created and calculated the disclosure index (INDEX). The disclosure index provides an aggregated measure of the quantity of disclosure within the companies' communications and facilitates a cross-sectional analysis of the frequency of disclosure between them (Guthrie and Abeysekera, 2006). The INDEX is aimed at measuring the quality of KPIs disclosures. For this reason, the index covers nine aspects of quality, such as the provision of (1) narrative commentary, (2) method of measurement (3) unit of measurement, (4) actual, (5) past and (6) projected values, (7) clear statement if KPIs are crucial for assessing the corporate performance, (8) explanation of choice, (9) KPIs in a table to enhance transparency. The elements included in the index are based on the desirable qualities of KPIs provided by the literature (e.g. projected (target) values (Bayne and Wee, 2019); clarity, pertinence, understandability (Bradley and Botchway, 2018)) and recommendations included in the EC guidelines (EC, 2017) and reporting standards (NAS 9, 2018; NFIS, 2017). Each item is assigned the same significance, and if the relevant information is available in the companies' report, it is an item with a value of " 1 ", and if it is not available- it is " 0 ". The index is calculated as the ratio of the sum of points assigned for each item mentioned in the reports to the total points available, which equals 9 .
Non-financial key performance indicators 
JAAR 23,1

148

In order to thoroughly analyze the set of data obtained from the reports, descriptive statistics, linear regression and selected statistical tests are performed. They are aimed at assessing the quality of KPI disclosures of the searched companies captured by the disclosure index (INDEX) and identifying the factors that determine the differences in the disclosure of KPIs related to environmental (ENV_KPI), social (SOC_KPI) and employee (EMPL_KPI) matters. Following Adams (2002), the factors examined are grouped into three categories: corporate characteristics represented by industry (INDUST), general contextual factors represented by main stakeholders such as investors (INVOI), employees (EMPOI), customers (CUSTOI), ecologist (ENVUI) as well as the internal context represented by reporting standard used by the company (STD) and the experience of the company in non-financial reporting (EXP). The stakeholders of the companies are identified following FernandezFeijoo et al. (2014). Following previous studies (see among others Cormier et al., 2005; Branco and Rodrigues, 2008; Gamerschlag et al., 2011; Al Farooque and Ahulu, 2017, Clarkson et al., 2019) we use a set of control variables that might influence the disclosure index (INDEX), namely size (LASSET), profitability (NPROFMRG) and solvency (SOLV). Size is measured with the natural logarithm of total assets, profitability as a ratio of profit to sales and solvency as a ratio of a company's total debt to its total assets. The financial data were collected from the Orbis Database.

Linear regression tests the pressure of different groups of stakeholders (EMPOI, CUSTOI, ENVUI, INVOI) as well as the impact of the standard used (STD) and experience (EXP) on the quality of disclosure (INDEX):

$$
\begin{aligned}
\mathrm{INDEX}= & b_{0}+b_{1} \mathrm{EMPOI}+b_{2} \mathrm{ENVUI}+b_{3} \mathrm{CUSTOI}+b_{4} \mathrm{INVOI}+b_{5} \mathrm{STD}+b_{6} \mathrm{EXP} \\
& +b_{7} \mathrm{SOLV}+b_{8} \mathrm{NPROFMRG}+b_{8} \mathrm{LASSET}+\zeta_{0}
\end{aligned}
$$

In order to examine how the disclosure quality differs in eight identified industries, analysis of variance (ANOVA) and Tukey's HSD test are carried out. For the purpose of checking whether the corporate characteristics, the general contextual factors and the internal context impact reporting of different groups of KPIs, we use the Mann-Whitney $U$ test and KruskalWallis ANOVA test.

Table 1 presents the description of the variables used, together with the information on how they were measured and the relevant sources.

\section{Empirical results and discussion}

\subsection{Descriptive statistics}

The results of the study allow us to state that $53 \%$ of the companies present non-financial information with the use of GRI guidelines while $27 \%$ use the local Polish standard, NFIS. However, almost $64 \%$ of the companies apply their own reporting frameworks in addition to GRI Standards or NFIS or instead of them.

Most companies included in the sample (93\%) present some non-financial KPIs, but only $62 \%$ of them use the term "key non-financial performance indicators" in their reports. Moreover, $41 \%$ of PIEs disclose the non-financial KPIs in a clear and coherent summarized form. The remaining companies present several indicators from different areas in different parts of the reports. Such an approach makes it impossible to conclude whether any of the indicators are actually taken into account by management while making strategic and operational decisions of the company or group. It is worth underlining that only $12 \%$ of PIEs explain the choice of presented indicators in their non-financial statements, while $33 \%$ disclose their measurement methods. Only $19 \%$ of the entities supplement the KPIs values with some narrative disclosure and explain their importance for decision making. Interestingly, $88 \%$ of the companies report current values of the indicators, while $62 \%$ 


\begin{tabular}{|c|c|c|c|c|}
\hline & Description & Measurement & References & Non-financial \\
\hline \multicolumn{4}{|c|}{ Quality of KPIs disclosures } & \\
\hline INDEX & $\begin{array}{l}\text { Index measuring the } \\
\text { quality of KPI } \\
\text { disclosures }\end{array}$ & $\begin{array}{l}\text { Measured as a sum of the nine } \\
\text { disclosure aspects expressed as 0/1 } \\
\text { values }\end{array}$ & $\begin{array}{l}\text { EC (2017), NAS 9 (2018), NFIS } \\
\text { (2017), Bayne and Wee } \\
\text { (2019), Bradley and } \\
\text { Botchway (2018) }\end{array}$ & indicators \\
\hline \multicolumn{4}{|c|}{ Type of KPIs disclosed } & 149 \\
\hline ENV_KPI & $\begin{array}{l}\text { Environmental KPIs } \\
\text { disclosed by } \\
\text { companies }\end{array}$ & $\begin{array}{l}\text { Average number of the disclosed } \\
\text { KPIs related to environmental } \\
\text { matters }\end{array}$ & $\begin{array}{l}\text { She and Michelon (2019), } \\
\text { Okazaki et al. (2020) }\end{array}$ & \\
\hline SOC_KPI & $\begin{array}{l}\text { Social KPIs disclosed } \\
\text { by companies }\end{array}$ & $\begin{array}{l}\text { Average number of the disclosed } \\
\text { KPIs related to social matters }\end{array}$ & $\begin{array}{l}\text { She and Michelon (2019), } \\
\text { Okazaki et al. (2020) }\end{array}$ & \\
\hline EMP_KPI & $\begin{array}{l}\text { Employee KPIs } \\
\text { disclosed by } \\
\text { companies }\end{array}$ & $\begin{array}{l}\text { Average number of the disclosed } \\
\text { KPIs related to employee matters }\end{array}$ & $\begin{array}{l}\text { She and Michelon (2019), } \\
\text { Okazaki et al. (2020) }\end{array}$ & \\
\hline \multicolumn{5}{|c|}{ Corporate characteristics } \\
\hline INDUST & $\begin{array}{l}\text { Industry represented } \\
\text { by the company }\end{array}$ & $\begin{array}{l}\text { Companies represent } 8 \text { industries: } \\
\text { consumer products (CONSUM), } \\
\text { technology (TECH), retail and } \\
\text { services (RET\&SERV), chemical } \\
\text { and raw materials (CHEM), finance } \\
\text { (FINANCE), production and } \\
\text { construction (PROD\&CONSTR), } \\
\text { medical (MEDICAL), fuel and } \\
\text { energy (FUEL\&ENERGY) }\end{array}$ & $\begin{array}{l}\text { The Warsaw Stock } \\
\text { Exchange industry } \\
\text { classification (WSE, 2020) }\end{array}$ & \\
\hline \multicolumn{5}{|c|}{ General contextual factors - stakeholder groups } \\
\hline INVOI & Investors & $\begin{array}{l}1=\text { investor-oriented industry } \\
0=\text { other }\end{array}$ & Fernandez-Feijoo et al. (2014) & \\
\hline EMPOI & Employees & $\begin{array}{l}1=\text { employees-oriented industry } \\
0=\text { other }\end{array}$ & Fernandez-Feijoo et al. (2014) & \\
\hline CUSTOI & Customers & $\begin{array}{l}1=\text { consumer-proximity industry } \\
0=\text { other }\end{array}$ & Fernandez-Feijoo et al. (2014) & \\
\hline ENVUI & Ecologists & $\begin{array}{l}1=\text { environmentally sensitive } \\
\text { industry } \\
0=\text { other }\end{array}$ & Fernandez-Feijoo et al. (2014) & \\
\hline \multicolumn{5}{|c|}{ Internal context } \\
\hline STD & $\begin{array}{l}\text { Reporting standard } \\
\text { used by a company }\end{array}$ & $\begin{array}{l}\text { GRI, NFIS or own reporting } \\
\text { framework }\end{array}$ & $\begin{array}{l}\text { Gao and Zhang (2001), } \\
\text { Rinaldi et al. (2014), Kaur and } \\
\text { Lodhia (2018), Hoffman et al. } \\
\text { (2018) }\end{array}$ & \\
\hline EXP & $\begin{array}{l}\text { Previous experience in } \\
\text { voluntary } \\
\text { sustainability } \\
\text { reporting }\end{array}$ & $\begin{array}{l}1=\text { experience in voluntary non- } \\
\text { financial disclosures } \\
0=\text { no experience }\end{array}$ & $\begin{array}{l}\text { Cormier et al. (2005), Ruhnke } \\
\text { and Gabriel (2013), Lock and } \\
\text { Seele (2016), Albertini (2013) }\end{array}$ & \\
\hline \multicolumn{5}{|c|}{ Control variables } \\
\hline \multirow[t]{2}{*}{ LASSET } & Size & $\begin{array}{l}\text { The natural logarithm of total } \\
\text { assets }\end{array}$ & $\begin{array}{l}\text { cf. Cormier et al. (2005), } \\
\text { Branco and Rodrigues (2008), } \\
\text { Gamerschlag et al. (2011), Al } \\
\text { Farooque and Ahulu (2017), } \\
\text { Clarkson et al. (2019) }\end{array}$ & \\
\hline & & & (continued) & $\begin{array}{r}\text { Table 1. } \\
\text { Variables description }\end{array}$ \\
\hline
\end{tabular}


JAAR 23,1
SOLV

\begin{tabular}{|c|c|c|c|}
\hline & Description & Measurement & References \\
\hline NPROFMRG & Profitability & $\begin{array}{l}\text { The ratio of net profit to sales. The } \\
\text { variable was standardized }\end{array}$ & $\begin{array}{l}\text { cf. Cormier et al. (2005), } \\
\text { Branco and Rodrigues (2008), } \\
\text { Gamerschlag et al. (2011), Al } \\
\text { Farooque and Ahulu (2017), } \\
\text { Clarkson } \text { et al. (2019) }\end{array}$ \\
\hline SOLV & Solvency & $\begin{array}{l}\text { The ratio of a company's total debt } \\
\text { to its total assets. The variable was } \\
\text { standardized }\end{array}$ & $\begin{array}{l}\text { cf. Cormier et al. (2005), } \\
\text { Branco and Rodrigues (2008), } \\
\text { Gamerschlag et al. (2011), Al } \\
\text { Farooque and Ahulu (2017), } \\
\text { Clarkson et al. (2019) }\end{array}$ \\
\hline
\end{tabular}

The ratio of a company's total debt to its total assets. The variable was standardized

Table 1.

also disclose their past values, usually from the previous financial year. $7 \%$ of sample companies inform about the target values, which can be regarded as an example of best practices. Still, $5 \%$ of the companies include some indicators in their reports but without any information about at least their present value.

The quality of the KPIs disclosures as captured by the INDEX is presented in Table 2. It is measured with index (INDEX) covering nine aspects of quality, such as the provision of (1) narrative commentary, (2) method of measurement (3) unit of measurement, (4) actual, (5) past and (6) projected values, (7) clear statement if KPIs are crucial for assessing the corporate performance, (8) explanation of choice, (9) KPIs in a table.

The environmentally sensitive industries such as chemical, fuel and energy, as well as production and construction have higher mean values of the index, which makes it possible to infer that they provide KPIs disclosure of better quality. The lowest INDEX value is observed in the financial sector.

The study identifies 575 different KPIs presented by companies. They are divided into three main categories related to environmental, social and employee issues (Table 3 ). The total number of observations equals 2,669. The most widely disclosed and diversified KPIs refer to employees and environment.

Variance inflation factor calculated for independent variables used in linear regression shows no multicollinearity in the tested model.

\subsection{Findings}

6.2.1 Factors determining the differences in the quality of KPI disclosures. One of the main concerns of the study is the quality of the KPIs disclosures of the sample companies. The

\begin{tabular}{lc} 
Industry & INDEX mean value \\
\hline CHEM & 0.559 \\
FUEL\&ENERGY & 0.481 \\
PROD\&CONST & 0.465 \\
CONSUM & 0.464 \\
TECH & 0.427 \\
MEDICAL & 0.413 \\
RET\&SERV & 0.392 \\
FINANCE & 0.378
\end{tabular}

Table 2.

INDEX mean value according to industry 
results of estimation of the linear regression are presented in Table 4, showing positive and significant effect of pressure from ecologists and standard used on the quality index of KPIs disclosures.

The positive sign of the coefficient shows that only ecologist (INVOI) and the standard used (STD) positively affect the quality of KPI disclosures (INDEX). This finding is in line with the results of the studies conducted by e.g.: Fernandez-Feijoo et al. (2014), Gamerschlag et al. (2011), Banerjee et al. (2003) that companies facing pressure from ecologists provide better nonfinancial disclosures. Furthermore, the results confirm that companies using the sustainability and non-financial reporting frameworks (such as GRI or NFIS) respond to the key topics and concerns that have been raised through stakeholder engagement and their disclosure is of better quality (cf:: Hoffmann et al., 2018; Akisik and Gal, 2011). Thus, the hypotheses H2a and $\mathrm{H} 3 \mathrm{a}$, which states that selected factors representing general contextual factors and internal context determine the quality of the corporate non-financial KPIs, are partially supported. Interestingly, the experience of the company in non-financial reporting and other stakeholders (investors, customers and employees) are unimportant for the quality of the KPI disclosures. The statistical results provided by the equation testing the hypothesis show that the equation represents a moderate degree of explanation because the adjusted $\mathrm{R}$-squared $\left(R^{2}\right)$ equals 0.105 . The model used collectively explains $10.5 \%$ of the variability of the INDEX around its mean.

The quality of disclosure was further compared based on analysis of variance (ANOVA). The assumptions required for the use of ANOVA are fulfilled (the population from which samples are drawn is normally distributed, the sample cases are independent of each other, there exists homogeneity of variance). ANOVA enabled examining the interdependences between the mean values of index (INDEX) and industries (INDUST). For industry, the value of $p$-values lower than $5 \%$ suggests that there is a significant difference between the mean values of INDEX in companies from various industries, thus confirming hypothesis H1b. Table 5 presents the results of the ANOVA test for mean values of the quality index in compared populations.

In order to further study the difference between selected industries in the quality of the index, the Tukey's HSD test is carried out. The parametric post-hoc Tukey's HSD test for

\begin{tabular}{lccccr}
\hline KPIs & No of KPIs & Mean & Variance & Std. deviation & Coef. Var \\
\hline ENV_KPI & 152 & 0.138 & 0.040 & 0.199 & 144.287 \\
SOC_KPI & 43 & 0.290 & 0.067 & 0.258 & 89.140 \\
EMP_KPI & 380 & 0.054 & 0.013 & 0.116 & 213.927
\end{tabular}

\begin{tabular}{|c|c|c|c|c|c|c|}
\hline$N=169$ & $b^{*}$ & Std. Error of b* & $b$ & Std. Error of $b$ & $t(160)$ & $p$-value \\
\hline Intercept & & & 0.285 & 0.103 & 2.763 & 0.006 \\
\hline SOLV & -0.018 & 0.079 & -0.003 & 0.015 & -0.225 & 0.822 \\
\hline NPROFMRG & -0.115 & 0.080 & -0.023 & 0.016 & -1.447 & 0.150 \\
\hline INVOI & 0.010 & 0.077 & 0.004 & 0.032 & 0.130 & 0.897 \\
\hline STD & 0.166 & 0.076 & 0.071 & 0.033 & 2.175 & 0.031 \\
\hline EMPOI & -0.005 & 0.092 & -0.002 & 0.036 & -0.058 & 0.953 \\
\hline CUSTOI & 0.044 & 0.112 & 0.017 & 0.044 & 0.388 & 0.699 \\
\hline ENVUI & 0.269 & 0.104 & 0.105 & 0.041 & 2.597 & 0.010 \\
\hline EXP & -0.028 & 0.086 & -0.013 & 0.039 & -0.327 & 0.744 \\
\hline LASSET & 0.058 & 0.096 & 0.005 & 0.009 & 0.605 & 0.546 \\
\hline
\end{tabular}

Note(s): All significant coefficients are in italics
Non-financial key

performance indicators

151

Table 3.

Number of KPIs disclosed by sample companies according to the category
Table 4.

The results of estimation of regression 
JAAR 23,1

152

different pairs confirms the ANOVA findings and shows significant differences between the mean values of INDEX for companies from chemical and financial sectors. Table 6 presents the results of Tukey's HSD test for mean values of the quality index in compared populations.

6.2.2 Factors determining the differences in the quantity of KPIs disclosed by the sample companies. The Mann-Whitney $U$ test is used to identify if the company's expertise in nonfinancial reporting and different group of stakeholders (employees-EMPOI, ecologistsENVUI, customers-CUSTOI and investors-INVOI) determine the differences in the disclosure of KPIs related to environmental (ENV_KPI), social (SOC_KPI) and employee (EMPL_KPI) matters (Table 7).

The Mann-Whitney $U$ test shows that there is a significant difference between median value of ENV_KPI and EMP_KPI, in companies influenced by ecologists and those without this influence. There is also a significant difference regarding the median number of social KPIs disclosed by the companies that are more and less experienced in non-financial reporting. This finding allows us to support the results of previous studies showing that more experienced companies disclose intensely on social issues (cf. Cormier et al., 2005; Ruhnke and Gabriel, 2013).

Table 5.

ANOVA tests for mean values of the quality index in compared populations

\begin{tabular}{lrrrrr}
\hline & \multicolumn{4}{c}{$\begin{array}{c}\text { Univariate results for each DV } \\
\text { Sigma-restricted parameterization } \\
\text { Effective hypothesis decomposition }\end{array}$} \\
Effect & df & SS & MS & $F$ & $p$-value \\
\hline Intercept & 1 & 25.472 & 25.472 & 694.334 & 0.000 \\
INDUST & 7 & 0.537 & 0.077 & 2.090 & 0.047 \\
Error & 161 & 5.906 & 0.037 & & \\
Total & 168 & 6.443 & & & \\
\hline
\end{tabular}

Table 6.

Tukey's HSD test for mean values of the quality index in compared populations

\begin{tabular}{llccccccccc}
\hline \multicolumn{10}{c}{ Tukey's HSD test; variable INDEX } \\
\multicolumn{8}{c}{ Approximate probabilities for post hoc tests } \\
Error: Between MS $=0.03668, \mathrm{df}=161.00$ & & & \\
Cell No. & INDUST & $\{1\}$ & $\{2\}$ & $\{3\}$ & $\{4\}$ & $\{5\}$ & $\{6\}$ & $\{7\}$ & $\{8\}$ \\
\hline 1 & CONSUM & & 0.999 & 0.900 & 0.466 & 0.723 & 1.000 & 0.998 & 1.000 \\
2 & TECH & 0.999 & & 1.000 & 0.438 & 0.996 & 0.999 & 1.000 & 0.997 \\
3 & RET\&SERV & 0.900 & 1.000 & & 0.081 & 1.000 & 0.909 & 1.000 & 0.921 \\
4 & CHEM & 0.466 & 0.438 & 0.081 & & 0.025 & 0.539 & 0.607 & 0.936 \\
5 & FINANCE & 0.723 & 0.996 & 1.000 & 0.025 & & 0.749 & 1.000 & 0.817 \\
6 & PROD\&CONST & 1.000 & 0.999 & 0.909 & 0.539 & 0.749 & & 0.998 & 1.000 \\
7 & MEDICAL & 0.998 & 1.000 & 1.000 & 0.607 & 1.000 & 0.998 & & 0.995 \\
8 & FUEL\&ENERGY & 1.000 & 0.997 & 0.921 & 0.936 & 0.817 & 1.000 & 0.995 & \\
\hline
\end{tabular}

Table 7.

Results of the MannWhitney $U$ test for compared populations and different KPIs

\begin{tabular}{|c|c|c|c|c|c|c|c|c|c|c|}
\hline \multirow[b]{2}{*}{ Variable } & \multicolumn{2}{|c|}{ BY EXP } & \multicolumn{2}{|c|}{ By EMPOI } & \multicolumn{2}{|c|}{ By ENVUI } & \multicolumn{2}{|c|}{ By CUSTOI } & \multicolumn{2}{|c|}{ By INVOI } \\
\hline & $U$ & $\begin{array}{c}p- \\
\text { value }\end{array}$ & $U$ & $\begin{array}{c}p- \\
\text { value }\end{array}$ & $U$ & $\begin{array}{c}p- \\
\text { value }\end{array}$ & $U$ & $\begin{array}{c}p- \\
\text { value }\end{array}$ & $U$ & $\begin{array}{c}p- \\
\text { value }\end{array}$ \\
\hline ENV_KPI & 2572.000 & 0.729 & 3409. & 0.610 & 574.000 & 0.002 & 3030. & 0.087 & 3160.000 & 0.77 \\
\hline SOC_KPI & 2082.500 & 0.012 & 3096.500 & 0.078 & 3268.500 & 0.272 & 3265.500 & 0.258 & 3097.500 & 0.56 \\
\hline EMP_KPI & 2423.000 & 0.375 & 3474.000 & 0.764 & 2799.500 & 0.016 & 3211.500 & 0.260 & 3128.000 & 0.700 \\
\hline
\end{tabular}


The disclosure is further compared based on Kruskal-Wallis ANOVA test to examine the interdependence between the KPIs disclosures and the reporting standard used by sample companies (STD). Kruskal-Wallis ANOVA test is used because the assumptions required for the use of ANOVA are no longer fulfilled in the case of the variables ENV_KPI, SOC_KPI and EMP_KPI. The $p$-value higher than $5 \%$ suggests that there is no significant difference between the median values of the social KPIs' disclosure in companies using GRI, NFIS, a mix of both standard and companies' own reporting frameworks. However, the median values of ENV_KPI and EMP_KPI disclosed differ significantly between companies using various reporting standards. More specifically, there is a significant difference between the average number of environmental and employee KPIs according to the standard used (Table 8). This finding is in line with the previous studies focusing on the non-financial disclosures in general (cf. Akisik and Gal, 2011; Gao and Zhang, 2001; Rinaldi et al., 2014; Kaur and Lodhia, 2018; Bradley and Botchway, 2018).

A similar analysis is conducted in order to examine the interdependence between the KPIs disclosures and the industry represented by disclosing companies (INDUST). The $p$-value higher than $5 \%$ suggests that there is no significant difference between the median values of social and employee KPIs disclosure in companies from different industries. However, the median values of environmental KPIs disclosure differ significantly in companies from various industries (Table 9). Thus, $\mathrm{H} 2 \mathrm{~b}$ and $\mathrm{H} 3 \mathrm{~b}$ are partially supported.

Table 10 contains the results of all statistical tests carried out to examine factors differentiating the KPIs disclosure quality, as well as the quantity of different groups of KPIs in research populations.

\section{Summary and conclusion}

As Venturelli et al. (2019b) argue, the real role of the Directive was not to introduce a strict set of non-financial reporting rules but rather to provide a way of harmonizing the content of nonfinancial disclosures in order to achieve a higher degree of information comparability (see also La Torre et al., 2018). However, market pressures on their own have not proven to be enough to achieve this aim and ensure that the non-financial information that companies report meets stakeholder needs (EC, 2020). It appears that there is still a long way to go before

\begin{tabular}{ll}
\hline Dependent variables & Test results (independent/grouping variable: STD) \\
\hline ENV_KPI & Median Test, Overall Median $=0.267$ \\
& Chi-Square $=9,05 d f=3 p=0.029$ \\
SOC_KPI & Median Test, Overall Median $=0.00000$ \\
& Chi-Square $=1.639 \mathrm{df}=3 p=0.651$ \\
EMP_KPI & Median Test, Overall Median $=0,184$ \\
& Chi-Square $=13,360 \mathrm{df}=3 p=0,004$
\end{tabular}

Non-financial key performance indicators

153

\begin{tabular}{ll}
\hline Dependent variables & Test results (independent /grouping variable: INDUST) \\
\hline ENV_KPI & Median Test. Overall Median $=0.267$ \\
& Chi-Square $=19.980 \mathrm{df}=7 p=0.005$ \\
SOC_KPI & Median Test. Overall Median $=0.00000$ \\
& Chi-Square $=4.399 \mathrm{df}=7 p=0.733$ \\
EMP_KPI & Median Test. Overall Median $=0.184$ \\
& Chi-Square $=13.302 \mathrm{df}=7 p=0.065$
\end{tabular}

Table 9. Kruskal-Wallis ANOVA test for median values of environmental, social and employee KPIs' disclosures in compared populations 
JAAR 23,1

154

harmonization of non-financial reporting practices is achieved (Venturelli et al., 2020; Venturelli and Pizzi, 2020). The causes of these problems are insufficiently detailed Directive requirements, myriad of overlapping and sometimes inconsistent private non-financial reporting frameworks and standards, as well as the lack of enforcement (EC, 2020). There are various guidelines companies can choose from while preparing KPIs disclosures, and none of them includes a definite list of KPIs. As our study shows, the main criticism expressed by the EC report on the assessment of the impact of the Directive 2014/95/EU is also valid for the KPIs. KPIs are not sufficiently comparable and hard to find even when they are reported (EC, 2020).

KPIs seem to be the element of non-financial reporting which should provoke the least controversy and dissenting voices as regards the increased scope of disclosures. KPIs are rooted in the management accounting system and, unlike narrative information, they have the characteristics that the accounting professionals, investors or financial analysts particularly value. They are often expressed in numbers (in a numerical form), which allows measuring and managing them. They are also - at least in theory - comparable in time and space in a more convenient way than non-financial narrative disclosures.

According to our findings, the total number of different KPIs presented by 169 sample companies equals 575 . One company presented 74 of them. The sample companies try to follow the new reporting requirements. However, the variety of the KPIs included in their communications and the way they are disclosed make the information provided quite heavy to digest for the users. Most companies provide a wide range of non-financial KPIs but without any explanations of why and how they are used by the management. They were also presented in various sections of the reports, which made their analysis and comparison difficult.

Investors were the main stakeholders who have inspired Directive 95/2014/EU, as well as Sustainable Finance Disclosure Regulation (Venturelli et al., 2020). Contrary to what might be expected, the quality of the KPIs disclosures does not depend on the investors' pressures, but it differs in companies facing pressures from ecologists and those without this pressure. Hypothesis 2a is therefore partially supported. This finding is in line with the stakeholder theory and earlier research showing that non-financial disclosure is more intensive in companies in which the stakeholders' awareness of the environmental issues is significant (cf. Gamerschlag et al., 2011; Banerjee et al., 2003). It suggests that the obligation to meet information needs of stakeholders other than investors, e.g. environment-oriented, might be an important determinant of companies' reporting decisions.

Ecologists were found to be the stakeholder group whose pressures are the most relevant regarding corporate non-financial reporting decisions. They influence not only the quality of the disclosures captured by the INDEX but also the quantity of all KPIs groups apart from social KPIs. This finding partially supports hypothesis $2 \mathrm{~b}$, according to which the company's

\begin{tabular}{|c|c|c|c|c|}
\hline \multirow[b]{2}{*}{ Factor } & \multicolumn{4}{|c|}{ Impact on } \\
\hline & INDEX & ENV_KPI & SOC_KPI & EMP_KPI \\
\hline
\end{tabular}

Table 10.

Summary of the Employees' pressures

importance of analyzed factors

Ecologists' pressures

Reporting standard used

Industry

Previous experience in voluntary non-financial reporting

Investors' pressures

$\begin{array}{llll}+ & + & - & + \\ + & + & - & + \\ + & + & - & - \\ - & - & + & - \\ - & - & - & - \\ - & - & - & - \\ - & - & - & -\end{array}$

Note(s): + means there is a significant difference, - means there is no significant difference 
stakeholder pressure determines the differences in the quantity of the non-financial KPIs disclosed by the companies.

The second important factor seems to be the standard used. As expected, the use of different standards results in differences not only in the quality of the KPIs disclosures (what supports hypothesis 3a) but also in the number of KPIs disclosed. Reporting standard is a significant factor which determines the differences in the quantity of the environment and employee-related KPIs disclosures, which is in line with hypothesis $3 \mathrm{~b}$. Further alignment of disclosure frameworks and regulation of non-financial reporting is therefore essential.

The industry is the third important determinant of the KPIs disclosure quality, which supports hypothesis 1a. It also significantly influences the differences in the quantity of environment-related KPIs disclosed by the sample companies. This finding is in line with hypothesis 1a and partially supports hypothesis $1 \mathrm{~b}$. Therefore, we conclude that focusing on the environment (including climate change) and introducing industry-related disclosure standards is a good direction in further regulation of non-financial reporting. Environmental issues and related information needs seem to be the most important areas of non-financial reporting, and therefore the recent EU developments in this regard are justified (EU, 2019; EU, 2020b).

Interestingly, contrary to our expectations based on the stakeholder theory assumptions, we are not able to support our claim expressed in hypothesis $4 \mathrm{a}$, which states that the company's experience in non-financial reporting determines the differences in the quality of the corporate non-financial KPIs disclosures. However, experience seems to be relevant for the quantity of social KPIs disclosed, and this finding partially supports hypothesis $4 \mathrm{~b}$.

We believe that the current study contributes to stakeholders theory and to the existing knowledge of corporate non-financial reporting as well as answers the call to engage in research which might be helpful in developing future non-financial reporting regulations by the EU (Korca and Costa, 2021). We introduce additional elements to the discussion on the influence of the internal context on the corporate reporting decisions-experience in voluntary non-financial reporting and the decision to use a specific reporting standard. We shed new light on the quality of the KPIs disclosure, which, to the best of our knowledge, has not been investigated before. Finally, the study may have implications for the regulatory bodies developing the non-financial reporting frameworks, and it should be noted that the regulatory non-financial reporting landscape is changing fast.

There are several new EU initiatives that will have an impact on the entities' non-financial KPIs disclosures. Article 8 of the Taxonomy Regulation (EU, 2020b) obliges non-financial undertakings covered by Directive 2014/95/EU to use three KPIs, namely the proportion of their turnover, their capital expenditure ("CapEx") and their operating expenditure ("OpEx") related to environmentally sustainable activities. The Sustainability Finance Disclosure Regulation (EU, 2019) is addressed to financial market participants (e.g. fund managers, pension providers, insurance-based investment product providers and credit institutions) and financial advisers, including certain insurance intermediaries and providers of investment advice, but it will also have an indirect impact on non-financial companies. The European Supervisory Authorities (ESAs) have proposed to the European Commission (EC) the draft Regulatory Technical Standards (RTS) on what will need to be disclosed under this regulation, including 18 principal and 46 additional KPIs (EBA, EIOPA and ESMA, 2021). The document divides KPIs into two groups (1) climate and other environment-related indicators and (2) social and employee matters, respect for human rights, anti-corruption and anti-bribery matters to capture the principal adverse impacts of investment decisions on sustainability factors. Finally, the new architecture of non-financial reporting in Europe has been proposed by the EFRAG (2021), and it will shape the EU non-financial reporting landscape in the years to come. 
JAAR 23,1

The study confirms that stakeholders determine the differences in the reporting practices of the companies. Given the importance of stakeholder engagement, not only investors but also other stakeholder groups must be involved in the EU consultation on KPIs standardization and disclosures to ensure their relevance and usefulness. Stakeholders interested in environmental issues significantly impact companies' KPIs reporting because this group is the most conscious and engaged in reporting practices. Further education of other stakeholder groups, including employees and customers, is therefore crucial. Pressure from stakeholders who are welleducated in sustainability issues combined with further development of the EU's institutional regulatory setting will shape the future of the non-financial reporting in the region. Large PIEs, which provide KPIs disclosures that are low in quality and high in number, need to abandon these ways in order to prepare for incoming changes. The changes in the corporate reporting will trigger changes in the way managers think about non-financial issues. KPIs not only need to be adequately presented. They also need to be managed and controlled. This way, reporting regulations will induce changes in management practices, and companies' actions will contribute to a sustainable global economy.

Our study is not free from limitations. One of them is the sample size that is reduced to Polish PIEs. Replication with more data from different countries could enable generalization and a meta-analytic combination of the study results. Furthermore, an interesting direction for future research would be to understand concrete situations regarding KPIs disclosure via long-term field studies conducted in companies. According to the results of our study, the disclosures on the environment-related KPIs seem to be particularly relevant. Therefore, investigating this specific area of corporate non-financial reporting in more detail would be especially desired.

\section{Note}

1. In contrast, some other guidelines (e.g. issued by International Integrated Reporting Council (IIRC), Sustainability Accounting Standards Board (SASB) or Task Force on Climate-related Financial Disclosures (TCFD)), favor investors and consider them to be the most important users of information provided.

\section{References}

Abdolmohammadi, M.J. (2005), "Intellectual capital disclosure and market capitalization", Journal of Intellectual Capital, Vol. 6 No. 3, pp. 397-416, doi: 10.1108/14691930510611139.

Accountancy Europe (2020), "Towards reliable non-financial information across Europe. Factsheet, audit and assurance", available at: https:/www.accountancyeurope.eu/wp-content/uploads/ Accountancy-Europe-NFI-assurance-practice_facthseet.pdf (accessed 20 June 2020).

Accounting Act (2016), "Accounting act of 15 December 2016 on changing the accounting act”, Dz.U. 2017 poz. 61, available at: http://isap.sejm.gov.pl/isap.nsf/DocDetails.xsp?id=WDU20170000061 (accessed 10 April 2020).

Adams, C. (2002), "Internal organisational factors influencing corporate social and ethical reporting: beyond current theorising", Accounting, Auditing and Accountability Journal, Vol. 15 No. 2, pp. 223-250, doi: 10.1108/09513570210418905.

Akisik, O. and Gal, G. (2011), "Sustainability in businesses, corporate social responsibility, and accounting standards: an empirical study", International Journal of Accounting and Information Management, Vol. 19 No. 3, pp. 304-324, doi: 10.1108/18347641111169287.

Al Farooque, O. and Ahulu, H. (2017), "Determinants of social and economic reportings: evidence from Australia, the UK and South African multinational enterprises", International Journal of Accounting and Information Management, Vol. 25 No. 2, pp. 177-200, doi: 10.1108/IJAIM-012016-0003. 
Albertini, E. (2013), "A descriptive analysis of environmental disclosure: a longitudinal study of French companies”, Journal of Business Ethics, Vol. 121 No. 2, pp. 233-254, doi: 10.1007/s10551013-1698-y.

Arvidsson, S. (2011), "Disclosure of non-financial information in the annual report: a managementteam perspective", Journal of Intellectual Capital, Vol. 12 No. 2, pp. 277-300, doi: 10.1108/ 14691931111123421.

Banerjee, S.B., Iyer, E.S. and Kashyap, R.K. (2003), "Corporate environmentalism: antecedents and influence of industry type”, Journal of Marketing, Vol. 67 No. 2, pp. 106-122, doi: 10.1509/jmkg. 67.2.106.18604.

Bayne, L. and Wee, M. (2019), "Non-financial KPIs in annual report narratives: Australian practice", Accounting Research Journal, Vol. 32 No. 1, pp. 7-19, doi: 10.1108/ARJ-02-2018-0033.

Beattie, V. and Thomson, S.J. (2007), "Lifting the lid on the use of content analysis to investigate intellectual capital disclosures", Accounting Forum, Vol. 31 No. 2, pp. 129-163, doi: 10.1016/j. accfor.2007.02.001.

Beck, A.C., Campbell, D. and Shrives, P.J. (2010), "Content analysis in environmental reporting research: enrichment and rehearsal of the method in a British-German context", The British Accounting Review, Vol. 42 No. 3, pp. 207-222, doi: 10.1016/j.bar.2010.05.002.

Bellucci, M. and Manetti, G. (2017), "Facebook as a tool for supporting dialogic accounting? Evidence from large philanthropic foundations in the United States", Accounting, Auditing and Accountability Journal, Vol. 30 No. 4, pp. 874-905, doi: 10.1108/AAAJ-07-2015-2122.

Bradley, O.J. and Botchway, G.O. (2018), "Communicating corporate social responsibility (CSR) in the coffee industry: an examination of indicators disclosed", Sustainability Accounting, Management and Policy Journal, Vol. 9 No. 2, pp. 139-164, doi: 10.1108/SAMPJ-02-2017-0015.

Branco, M.C. and Rodrigues, L.L. (2008), "Factors influencing social responsibility disclosure by Portuguese companies", Journal of Business Ethics, Vol. 83 No. 4, pp. 685-701, doi: 10.1007/ s10551-007-9658-z.

CDSB (2018), "CDSB Framework Advancing and aligning disclosure of environmental information in mainstream reports for reporting environmental information, natural capital and associated business impacts", Climate Disclosure Standards Board, available at: https://www.cdsb.net/ sites/default/files/cdsb_framework_2.1.pdf (accessed 15 June 2020.

Clarkson, P., Li, Y., Richardson, G. and Tsang, A. (2019), "Causes and consequences of voluntary assurance of CSR reports: international evidence involving Dow Jones sustainability index inclusion and firm valuation”, Accounting, Auditing and Accountability Journal, Vol. 32 No. 8, pp. 2451-2474, doi: 10.1108/AAAJ-03-2018-3424.

Cormier, D., Magnan, M. and Van Velthoven, B. (2005), "Environmental disclosure quality in large German companies: economic incentives, public pressures or institutional conditions?", European Accounting Review, Vol. 14 No. 1, pp. 3-39, doi: 10.1080/0963818042000339617.

Crane, A. and Livesey, S. (2003), "Are you talking to me? Stakeholder communication and the risks and rewards of dialogue”, in Andriof, J., Waddock, S., Rahman, S. and Husted, B. (Eds), Unfolding Stakeholder Thinking 2: Relationships, Communication, Reporting and Performance, Greenleaf Publishing, Sheffield, pp. 39-52.

De Villiers, C. (2018), "Stakeholder requirements for sustainability reporting”, in De Villiers, C. and Maroun, W. (Eds), Sustainability Accounting and Integrated Reporting, Routledge, Abingdon, pp. 57-63.

De Villiers, C. and Marques, A. (2016), "Corporate social responsibility, country-level predispositions, and the consequences of choosing a level of disclosure", Accounting and Business Research, Vol. 46 No. 2, pp. 167-195, doi: 10.1080/00014788.2015.1039476.

Deegan, C. and Gordon, B. (1996), "A study of the environmental disclosure practices of Australian corporations", Accounting and Business Research, Vol. 26 No. 3, pp. 187-199, doi: 10.1080/ 00014788.1996.9729510.
Non-financial key performance indicators 
JAAR 23,1

158
Di Tullio, P., Valentinetti, D., Nielsen, C. and Rea, M.A. (2019), "In search of legitimacy: a semiotic analysis of business model disclosure practices", Meditari Accountancy Research, Emerald Group Publishing, Vol. 28 No. 5, pp. 863-887, doi: 10.1108/MEDAR-02-2019-0449.

Doni, F., Bianchi Martini, S., Corvino, A. and Mazzoni, M. (2019), "Voluntary versus mandatory nonfinancial disclosure”, Meditari Accountancy Research, Vol. 28 No. 5, pp. 781-802, doi: 10.1108/ medar-12-2018-0423.

Dumitru, M., Dyduch, J., Guse, R.-G. and Krasodomska, J. (2017), "Corporate reporting practices in Poland and Romania-an ex-ante study to the new non-financial reporting European directive", Accounting in Europe, Vol. 14 No. 3, pp. 279-304, doi: 10.1080/17449480.2017.1378427.

EBA, EIOPA and ESMA (2021), "Final report on draft regulatory technical standards with regard to the content, methodologies and presentation of disclosures pursuant to article 2a, article 4(6) and (7), article 8(3), article 9(5), article 10(2) and article 11(4) of regulation (EU) 2019/2088”, available at: https:/www.esma.europa.eu/press-news/esma-news/three-european-supervisoryauthorities-publish-final-report-and-draft-rts (accessed 27 March 2021).

EC (2017), "Guidelines on non-financial reporting (methodology for reporting non-financial information)", available at: https://eur-lex.europa.eu/legal-content/EN/TXT/?uri=CELEX: 52017XC0705(01) (accessed 2 March 2020).

EC (2019), "Guidelines on reporting climate-related information. Guidelines on non-financial reporting: supplement on reporting climate-related information", available at: https://eur-lex.europa.eu/ legal-content/EN/TXT/?uri=CELEX\%3A52019XC0620\%2801\%29 (accessed 10 April 2020).

EC (2020), "Inception impact assessment, proposal for a regulation as regards disclosure of nonfinancial information by certain undertakings and groups document Ares(2020)580716", available at: https://eur-lex.europa.eu/legal-content/EN/TXT/?uri=pi_com:Ares (2020)580716 (accessed 10 May 2020).

EFFAS, DVFA (2010), "KPIS for ESG. A guideline for the integration of ESG into Financial analysis of corporate valuation. Version 3.0", The European Federation of Financial Analysts Societies, Society of Investment Professionals in Germany, available at: https://www.dvfa.de/fileadmin/ downloads/Publikationen/Standards/KPIs_for_ESG_3_0_Final.pdf (accessed 10 July 2020).

EFRAG (2020), "Progress report of the Project Task Force on preparatory work for the elaboration of possible EU non-financial reporting standards (PTF-NFRS). Status and preliminary high-level assessment points", available at: https://www.efrag.org/Assets/Download?assetUrl=\%2Fsites $\% 2$ Fwebpublishing $\% 2$ FSiteAssets $\%$ 2FPTF-NFRS $\% 2520$ Progress $\% 2520$ Report $\% 2520$ Final. pdf (accessed 23 November 2020).

EFRAG (2021), "Proposals for a relevant and dynamic EU sustainability reporting standard setting", Final Report, available at: https://ec.europa.eu/info/sites/info/files/business_economy_euro/ banking_and_finance/documents/210308-report-efrag-sustainability-reporting-standardsetting_en.pdf (accessed 20 March 2021).

EU (2014), "Directive 2014/56/EU of the European Parliament and of the Council of April 162014 amending Directive 2006/43/EC on statutory audits of annual accounts and consolidated accounts", available at: https://eur-lex.europa.eu/legal-content/EN/TXT/?uri=celex \% 3A32014L0056 (accessed 10 May 2020).

EU (2019), "Regulation (EU) 2019/2088 of the European Parliament and of the Council of 27 November 2019 on sustainability-related disclosures in the financial services sector (Text with EEA relevance)", available at: https://eur-lex.europa.eu/eli/reg/2019/2088/oj (accessed 23 November 2020).

EU (2020a), "Environment. Eco-management and audit scheme. Premium benefits through EMAS", available at: https://ec.europa.eu/environment/emas/emas_for_you/premium_benefits_ through_emas_en.htm (accessed 10 July 2020).

EU (2020b), "Regulation (EU) 2020/852 of the European Parliament and of the Council of 18 June 2020 on the establishment of a framework to facilitate sustainable investment, and amending Regulation 
(EU) 2019/2088 (Text with EEA relevance)", available at: https:/eur-lex.europa.eu/legal-content/ EN/TXT/PDF/?uri=CELEX:32020R0852\&from=PL (accessed 23 November 2020).

Eurosif (2016), "European SRI study", available at: http://www.eurosif.org/wp-content/uploads/2016/ 11/SRI-study-2016-HR.pdf (accessed 10 June 2020).

Fernandez-Feijoo, B., Romero, S. and Ruiz, S. (2013), "Effect of stakeholders' pressure on transparency of sustainability reports within the GRI framework", Journal of Business Ethics, Vol. 122 No. 1, pp. 53-63, doi: 10.1007/s10551-013-1748-5.

Fifka, M.S. (2013), "Corporate responsibility reporting and its determinants in comparative perspective - a review of the empirical literature and a meta-analysis", Business Strategy and the Environment, Vol. 22 No. 1, pp. 1-35, doi: 10.1002/bse.729.

Fifka, M.S. and Drabble, M. (2012), "Focus and standardization of sustainability reporting - a comparative study of the United Kingdom and Finland", Business Strategy and the Environment, Vol. 21 No. 7, pp. 455-474, doi: 10.1002/bse.1730.

Fijałkowska, J., Krasodomska, J., Macuda, M. and Mućko, P. (2019), Sprawozdawczość niefinansowa Regulacja $i$ standaryzacja raportowania niefinansowego przedsiębiorstw, Wydawnictwo Naukowe Uniwersytetu Szczecińskiego, Szczecin.

Freeman, R.E. (1984), Strategic Management: A Stakeholder Approach, Pitman, Boston.

FSR (2020), "Raporty spółek”, available at: https://standardy.org.pl/raporty-spolek (accessed 5 April 2019).

Gamerschlag, R., Möller, K. and Verbeeten, F. (2011), "Determinants of voluntary CSR disclosure: empirical evidence from Germany”, Review of Managerial Science, Vol. 5 Nos 2/3, pp. 233-262, doi: 10.1007/s11846-010-0052-3.

Gao, S. and Zhang, J. (2001), "A comparative study of stakeholder engagement approaches in social auditing", in Andriof, J. and McIntosh, M. (Eds), Perspectives on Corporate Citizenship, Greenleaf Publishing, Sheffield, pp. 239-55.

GRI (2021a), "GRI standards", available at: https://www.globalreporting.org/how-to-use-the-gristandards/gri-standards-english-language/ (accessed 27 March 2021).

GRI (2021b), "GRI sustainability disclosure database", available at: https://database.globalreporting. org/SDG-12-6/Global-Tracker (accessed 20 March 2021).

Guthrie, J. (2014), "In defence of disclosure studies and the use of content analysis: a research note", Journal of Intellectual Capital, Vol. 15 No. 2, doi: 10.1108/JIC-03-2014-0029.

Guthrie, J. and Abeysekera, I. (2006), "Content analysis of social, environmental reporting: what is new?”, Journal of Human Resource Costing and Accounting, Vol. 10 No. 2, pp. 114-126, doi: 10. 1108/14013380610703120.

Haski-Leventhal, D. (2013), "Employee engagement in CSR: the case of payroll giving in Australia", Corporate Social Responsibility and Environmental Management, Vol. 20 No. 2, pp. 113-128, doi: 10.1002/csr.1287.

Ho, L.C.J. and Taylor, M.E. (2007), "An empirical analysis of triple-bottom line reporting and its determinants: evidence from the United States and Japan", Journal of International Financial Management and Accounting, Vol. 18 No. 2, pp. 123-150, doi: 10.1111/j.1467-646X.2007.01010.x.

Hoffmann, E., Dietsche, C. and Hobelsberger, C. (2018), "Between mandatory and voluntary: nonfinancial reporting by German companies", Nachhaltigkeits Management Forum, Vol. 26 Nos 1-4, pp. 47-63, doi: 10.1007/s00550-018-0479-6.

Hussainey, K. and Salama, A. (2010), "The importance of corporate environmental reputation to investors", Journal of Applied Accounting Research, Vol. 11 No. 3, pp. 229-241, doi: 10.1108/ 09675421011088152.

Idowu, S.O., Capaldi, N., Zu, L. and Das Gupta, A. (2013), Encyclopedia of Corporate Social Responsibility, Springer-Verlag, Berlin, Heidelberg.

IIRC (2013), "International integrated reporting framework", available at: https://integratedreporting. org/resource/international-ir-framework/ (accessed 10 June 2020).
Non-financial key performance indicators 
JAAR 23,1

Jenkins, H. and Yakovleva, N. (2006), "Corporate social responsibility in the mining industry: exploring trends in social and environmental disclosure", Journal of Cleaner Production, Vol. 14 No. 3, pp. 271-284, doi: 10.1016/j.jclepro.2004.10.004.

Kaur, A. and Lodhia, S. (2018), "Stakeholder engagement in sustainability accounting and reporting: a study of Australian local councils", Accounting, Auditing and Accountability Journal, Vol. 31 No. 1, pp. 338-368, doi: 10.1108/aaaj-12-2014-1901.

Korca, B. and Costa, E. (2021), "Directive 2014/95/EU: building a research agenda”, Journal of Applied Accounting Research, Vol. 22 No. 3, pp. 401-422, doi: 10.1108/JAAR-05-2020-0085.

Krasodomska, J. (2013), "Kluczowe wskaźniki efektywności w praktyce spółek notowanych na Giełdzie Papierów Wartościowych w Warszawie”, Zeszyty Teoretyczne Rachunkowości, Vol. 73 No. 129 , pp. $75-87$.

Krasodomska, J. and Zarzycka, E. (2020), "Key performance indicators disclosure in the context of the EU directive: when does stakeholder pressure matter?”, Meditari Accountancy Research, Vol. 29 No. 7, pp. 1-30, doi: 10.1108/MEDAR-05-2020-0876.

La Torre, M., Sabelfeld, S., Blomkvist, M., Tarquinio, L. and Dumay, J. (2018), "Harmonising nonfinancial reporting regulation in Europe: practical forces and projections for future research", Meditari Accountancy Research, Vol. 26 No. 4, pp. 598-621, doi: 10.1108/MEDAR-02-2018-0290.

Lehner, O.M. and Harrer, T. (2019), "Accounting for economic sustainability: environmental, social and governance perspectives”, Journal of Applied Accounting Research, Vol. 20 No. 4, pp. 365-371, doi: 10.1108/JAAR-06-2019-0096.

Lim, S., Matolcsy, Z. and Chow, D. (2007), "The association between board composition and different types of voluntary disclosure", European Accounting Review, Vol. 16 No. 3, pp. 555-583, doi: 10. 1080/09638180701507155.

Lisi, I.E. (2018), "Determinants and performance effects of social performance measurement systems", Journal of Business Ethics, Vol. 152 No. 1, pp. 225-25, doi: 10.1007/s10551-016-3287-3.

Lock, I. and Seele, P. (2016), "The credibility of CSR (corporate social responsibility) reports in Europe. Evidence from a quantitative content analysis in 11 countries", Journal of Cleaner Production, Vol. 122, pp. 186-200, doi: 10.1016/j.jclepro.2016.02.060.

Lombard, M., Snyder-Duch, J. and Bracken, C.C. (2002), "Content analysis in mass communication: assessment and reporting of intercoder reliability", Human Communication Research, Vol. 28 No. 4, pp. 587-604, doi: 10.1111/j.1468-2958.2002.tb00826.x.

Loprevite, S., Raucci, D. and Rupo, D. (2020), "KPIs reporting and financial performance in the transition to mandatory disclosure: the case of Italy", Sustainability, Vol. 12, pp. 5195-5219, doi: $10.3390 /$ su12125195.

Michelon, G., Pilonato, S. and Ricceri, F. (2015), "CSR reporting practices and the quality of disclosure: an empirical analysis", Critical Perspectives on Accounting, Vol. 33, pp. 59-78, doi: 10.1016/j.cpa. 2014.10.003.

Miles, S. (2019), "Stakeholder theory and accounting", in Jeffrey, S., Harrison, J.B., BarneyFreeman, R.E. and Phillips, R.A. (Eds), The Cambridge Handbook of Stakeholder Theory, Cambridge University Press, Cambridge, pp. 173-210, doi: 10.1017/9781108123495.

Ministry of Finance (2019), "Raportowanie rozszerzonych informacji niefinansowych za 2017 rok zgodnie $z$ ustawą o rachunkowości-pierwsze doświadczenia i dobre praktyki Ministerstwo Finansów", available at: https://www.gov.pl/web/finanse/konferencja-mf-w-zakresieraportowania-niefinansowego-w-dniu-11-marca-2019 (accessed 10 June 2020).

Mio, C., Fasan, M., Marcon, C. and Panfilo, S. (2020), "The predictive ability of legitimacy and agency theory after the implementation of the EU directive on non-financial information", Corporate Social Responsibility and Environmental Management, Vol. 27 No. 6, pp. 2465-2476, doi: 10.1002/ csr.1968. 
Mishra, S. and Suar, D. (2010), "Do stakeholder management strategy and salience influence corporate social responsibility in Indian companies?", Social Responsibility Journal, Vol. 6 No. 2, pp. 306-327, doi: 10.1108/17471111011051784.

Monciardini, D. (2016), “The 'coalition of the unlikely' driving the EU regulatory process of nonfinancial reporting", Social and Environmental Accountability Journal, Routledge, Vol. 36, pp. 76-89, doi: 10.1080/0969160X.2016.1149302.

NAS 9 (2018), "Krajowy standard rachunkowości Nr 9 Sprawozdanie z działalności”, available at: https://www.gov.pl/web/finanse/krajowe-standardy-rachunkowosci (accessed 10 May 2020).

NFIS (2017), Standard Informacji Niefinansowych, SEG, available at: https://www.seg.org.pl/p1/ standard-informacji-niefinansowych-sin (accessed 27 March 2021).

Nicolo, G., Zanellato, G., Manes-Rossi, F. and Tiron-Tudor, A. (2020), "Corporate reporting metamorphosis: empirical findings from state-owned enterprises", Public Money and Management, Vol. 41 No. 2, pp. 1-10, doi: 10.1080/09540962.2020.1719633.

Okazaki, S., Plangger, K., West, W. and Menéndez, H. (2020), "Exploring digital corporate social responsibility communications on Twitter", Journal of Business Research, Vol. 117, pp. 675-682, doi: 10.1016/j.jbusres.2019.09.006.

Parmenter, D. (2015), Key Performance Indicators. Developing, Implementing an Using Winning KPIs, Wiley, New Jersey.

Pedersen, E.R. (2006), "Making corporate social responsibility (CSR) operable: how companies translate stakeholder dialogue into practice”, Business and Society Review, Vol. 111 No. 2, pp. 137-163, doi: 10.1111/j.1467-8594.2006.00265.x.

Pizzi, S., Venturelli, A. and Caputo, F. (2020), “The 'comply-or-explain' principle in directive 95/2014/ EU. A rhetorical analysis of Italian PIEs", Sustainability Accounting, Management and Policy Journal, Vol. 12 No. 1, pp. 30-50, doi: 10.1108/SAMPJ-07-2019-0254.

Prado-Lorenzo, J.-M., Gallego-Alvarez, I. and Garcia-Sanchez, I.M. (2009), "Stakeholder engagement and corporate social responsibility reporting: the ownership structure effect", Corporate Social Responsibility and Environmental Management, Vol. 16 No. 2, pp. 94-107, doi: 10.1002/csr.189.

Rimmel, G. and Jonäll, K. (2020), “Theories of accounting for sustainability”, in Rimmel, G. (Ed.), Accounting for Sustainability, Routledge.

Rinaldi, L., Unerman, J. and Tilt, C.A. (2014), "The role of stakeholder engagement and dialogue in the sustainability accounting and reporting process", in Bebbington, J., Unerman, J. and O'Dwyer, B. (Eds), Sustainability Accounting and Accountability, Routhledge, New York, pp. 86-107.

Rodrigue, M., Magnan, M. and Boulianne, E. (2013), "Stakeholders' influence on environmental strategy and performance indicators: a managerial perspective", Management Accounting Research, Vol. 24 No. 4, pp. 301-316, doi: 10.1016/j.mar.2013.06.004.

Ruhnke, K. and Gabriel, A. (2013), "Determinants of voluntary assurance on Sustainability reports: an empirical analysis", Journal of Business Economy, Vol. 83, pp. 1063-1091, doi: 10.1007/s11573013-0686-0.

Salehi, M., Tarighi, H. and Rezanezhad, M. (2019), "Empirical study on the effective factors of social responsibility disclosure of Iranian companies", Journal of Asian Business and Economic Studies, Vol. 26 No. 1, pp. 34-55, doi: 10.1108/JABES-06-2018-0028.

SASB (2013), "Standards outcome report. Financials", available at: https://www.sasb.org/wp-content/ uploads/2014/02/SASB-Standards-Outcome-Report.pdf (accessed 2 July 2020).

She, C. and Michelon, G. (2019), "Managing stakeholder perceptions: organized hypocrite in CSR disclosures on Facebook", Critical Perspectives on Accounting, Vol. 61, pp. 54-76, doi: 10.1016/j. cpa.2018.09.004.

Skoczylas, W. (2019), "Społeczna odpowiedzialność biznesu w świetle analizy zawartości raportów niefinansowych spółek makrosektora produkcja przemysłowa i budowlano-montażowa", Zeszyty Teoretyczne Rachunkowości, Vol. 103 No.159, pp. 169-182.
Non-financial key performance indicators 
JAAR 23,1

162

Szabó, D.G. and Sørensen, K.E. (2015), "New EU directive on the disclosure of nonfinancial information (CSR)", European Company and Financial Law Review, Vol. 12-3, doi: 10.1515/ecfr2015-0307.

Szadziewska, A., Spigarska, E. and Majerowska, E. (2018), "The disclosure of non-financial information by stock- exchange-listed companies in Poland, in the light of the changes introduced by the Directive 2014/95/EU”, Zeszyty Teoretyczne Rachunkowości, Vol. 99 No. 155, pp. 65-95.

Szewc, M. and Abec, A. (2015), "CSR stanie sie obowiązkowym elementem sprawozdawczości spółek, Raport. Odpowiedzialny Biznes w Polce. Dobre Praktyki 2014”, Forum Odpowiedzialnego Biznesu, available at: http://odpowiedzialnybiznes.pl/wp-content/uploads/2015/04/RaportOdpowiedzialny-biznes-w-Polsce-2014.-Dobre-praktyki_Forum_Odpowiedzialnego_Biznesu.pdf (accessed 10 May 2020).

Tilt, C.A. (2016), "Corporate social responsibility research: the importance of context", International Journal of Corporate Social Responsibility, Vol. 1 No. 2, pp. 1-9, doi: 10.1186/s40991-016-0003-7.

Ullmann, A.A. (1985), "Data in search of a theory:A critical examination of the relationships among social performance, social disclosure, and economic performance of US Firms", The Academy of Management Review, Vol. 10 No. 3, pp. 540-555, doi: 10.5465/amr.1985.4278989.

UN Global Compact (2020), "Global compact self-assessment tool, Confederation of Danish industry", Ministry of Business and Growth in Denmark. The Danish Institute for Human Rights, Investment Fund for Developing Countries, available at: https://globalcompactselfassessment. org/aboutthistool (accessed 10 July 2020).

UNCTAD (2019), "Guidance on core indicators for entity reporting on contribution towards implementation of the sustainable development goals", available at: https://unctad.org/en/ PublicationsLibrary/diae2019d1_en.pdf (accessed 30 May 2020).

Venturelli, A. and Pizzi, S. (2020), "What drives the level of nonfinancial assurance in PIEs? Empirical evidence on the European firms listed on Forbes 2000", in Del Baldo, M., Dillard, J., Baldarelli, M.-G. and Ciambotti, M. (Eds), Accounting, Accountability and Society, Springer International Publishing, pp. 245-265.

Venturelli, A., Caputo, F., Cosma, S., Leopizzi, R. and Pizzi, S. (2017), "Directive 2014/95/EU: are Italian companies already compliant?", Sustainability, Vol. 9 No. 8, p. 1385, doi: 10.3390/su9081385.

Venturelli, A., Caputo, F., Leopizzi, R. and Pizzi, S. (2019a), "The state of art of corporate social disclosure before the introduction of non-financial reporting directive: a cross country analysis", Social Responsibility Journal, Vol. 15 No. 4, pp. 409-423, doi: 10.1108/SRJ-12-2017-0275.

Venturelli, A., Pizzi, S., Leopizzi, R. and Caputo, F. (2019b), "Integrated reporting assurance: first evidences after the transposition of Directive 95/2014/EU”, Italian Accounting Review, Vols 9-12, pp. 91-103.

Venturelli, A., Pizzi, S., Caputo, F. and Principale, S. (2020), "The revision of non-financial reporting directive: a critical lens on the comparability principle", Business Strategy and the Environment, Vol. 29 No. 8, pp. 3584-3597, doi: 10.1002/bse.2598.

Waniak-Michalak, H. (2017), "Porównywalność w czasie informacji o wynikach działalności społecznie odpowiedzialnej firm raportujących według zasad GRI”, Zeszyty Teoretyczne Rachunkowości, Vol. 91 No. 147, pp. 129-143.

WSE (2020), Warsaw stock exchange industry classification, available at: https://www.gpw.pl/spolki (accessed 30 January 2020).

\section{Corresponding author}

Joanna Krasodomska can be contacted at: joanna.krasodomska@uek.krakow.pl

For instructions on how to order reprints of this article, please visit our website:

www.emeraldgrouppublishing.com/licensing/reprints.htm

Or contact us for further details: permissions@emeraldinsight.com 